Original Article

\title{
Distribution of commensal rodents in rain-fed and irrigated areas of Swat district, Khyber Pakhtunkhwa, Pakistan
}

\author{
Distribuição de roedores comensais em áreas irrigadas e chuvosas do distrito de Swat, \\ Khyber Pakhtunkhwa, Paquistão
}

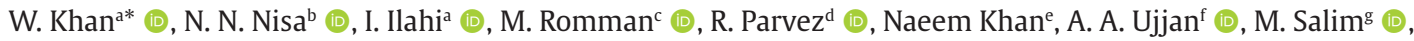 \\ A. Hussaing (D) U. Habiba ${ }^{g}$ (D) and A. Alam ${ }^{\text {h }}$ (D) \\ aUniversity of Malakand, Department of Zoology, Lower Dir, Khyber Pakhtukhwa, Pakistan

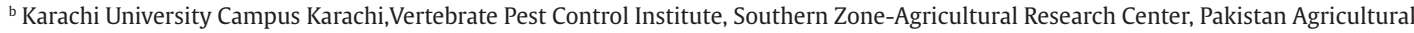 \\ Research Council, old Block 9\&10, Karachi, Pakistan \\ 'University of Chitral, Department of Botany, Chitral, Pakistan \\ ${ }^{d}$ Government Girls Degree College Dargai, Department of Botany, Malakand, KP, Pakistan \\ eIslamia College University, Department of Zoology, Peshawar, Pakistan \\ fUniversity of Sindh, Institute of Plant Sciences, Allams I.I. Kazi Campus, Jamshoro, Pakistan \\ gUniversity of Haripur, Department of Forestry and Wildlife Management, Haripur, Pakistan \\ hHazara University Mansehra, Department of Zoology, Mansehra, Pakistan
}

\begin{abstract}
Distribution pattern and relative abundance of the agricultural rodent pests of rain-fed and irrigated areas of district Swat Khyber Pakhtunkhwa, Pakistan were recorded from April 2011 to November 2013 using wire mesh live traps. A total of 350 rodents (269 Rattus rattus and 81 Mus musculus) were captured under 2268 trap nights (trap success: 0.15 ). Regression of daily captures on cumulative captures revealed an estimate of 350 rodents from all the sampled structures with an average of 21.8 rodents per crop field. House rats ( $R$. rattus; $76.8 \%$ of captures) were numerically dominant in almost all types of agricultural fields, and were significantly different from the mice (Mus musculus; $23.1 \%$ of captures). Both species were found together in some fields. The sex ratio revealed that males outnumbered the females in both of the reported species.
\end{abstract}

Keywords: rodents of agricultural importance, vertebrate pests, Rattus rattus, Mus musculus, population. dynamics.

\begin{abstract}
Resumo
O padrão de distribuição e a abundância relativa de pragas de roedores agrícolas nas áreas irrigadas e irrigadas do distrito Swat Khyber Pakhtunkhwa, Paquistão foram registrados de abril de 2011 a novembro de 2013 usando armadilhas vivas de malha de arame. Um total de 350 roedores (269 Rattus rattus e 81 Mus musculus) foram capturados em 2268 noites de armadilha (sucesso da armadilha: 0,15). A regressão das capturas diárias em capturas cumulativas revelou uma estimativa de 350 roedores de todas as estruturas amostradas, com uma média de 21,8 roedores por campo agrícola. Os ratos domésticos ( $R$. rattus; $76,8 \%$ das capturas) foram numericamente dominantes em quase todos os tipos de campos agrícolas e foram significativamente diferentes dos camundongos (Mus musculus; 23,1\% das capturas). Ambas as espécies foram encontradas juntas em alguns campos. A proporção de sexo revelou que os machos superaram as fêmeas em ambas as espécies relatadas.
\end{abstract}

Palavras-chave: roedores de importância agrícola, pragas de vertebrados, Rattus rattus, Mus musculus, dinâmica populacional.

\section{Introduction}

Rodent pests are living with man either in agriculture or in residence and will not leave their company in future. These pests not only threaten livelihoods directly, but also by forcing the affected spend resources on trying to eliminate the infestation. So, they not only depend on man for their food and shelter but also cause infestation in agricultural fields, shops, homes, godowns and transmit infectious diseases to human and their livestock directly by biting or indirectly by vector.

Amongst the vertebrate pests, rodents rank the first which directly depend on human production and urban habitats. Rodents are characterized by rapid sexual maturity, short gestation period, large litter size, opportunistic foraging behavior and gnawing teeth (Aplin et al., 2003). 
Rodents account for about $44 \%$ of the world's mammals and reside in every continent except Antarctica (Wolff and Sherman, 2007). There are about 2000 species of rodents known to science (Wilson and Reeder, 1993) and only 5-10\% are agricultural pests (Stenseth et al., 2003).

Losses by rodents leads to under-nourishment and starvation. For a long time, farmers have considered rodents as an inevitable pest in their fields and are serious competitors with people for cereals, and occasional massive rodent population outbreaks ruin harvests (Stenseth et al., 2003). Rats and mice have a significant role in economic losses of developing countries. In Asia rats can consume crops which could be fed to 2000 million people in the whole year. In Asia pre-harvest loss to rice is 5-10\%, this loss could be accounted roughly for 30 million tons, sufficient to feed nearly 200 million people for a year (Singleton, 2003). For Tanzania, the average annual yield loss of maize is estimated to be around 5 to 15\% (Makundi et al., 1991). This is comparable up to more than 400,000 tonnes of maize, equivalent to an amount that could feed 2.3 million people for a whole year (Leirs, 2003).

In Pakistan rats and mice exert serious losses to all major crops which damage rice and wheat amounts almost Rs. 2 billion annually (Khan, 1990). The estimated cost losses in different agricultural fields by the field rodents in a bad year in Pakistan are: rice Rs. 193 million, wheat 472 million, sugarcane and groundnut 534 million (Shafi et al., 1990).

It was hypothesized that about 280 million undernourished people could be benefited if more attention is be paid for reducing pre and post-harvest losses by rodents, 826 million people (inhabitants of about 113 countries) are undernourished including 558 million in Asia, 212 million in Africa, 52 million in Latin America and 3.8 million people in Europe are most susceptible to a long-term rise in food prices (Meerburg et al., 2009). However, there is no way to eradicate rodents totally but one can optimize the population and can protect the crops from damages of rodents (Leirs, 2003). During the last several decades, urbanization and intensive agricultural practices have been carried out to meet the increasing food demands of human population. Such practices are better for the survival of rodent pests.

There are 43 different species of rodents found in Pakistan, mostly rats and mice, but also include porcupine, giant flying squirrels and desert gerbils. Fifteen species (34.8\%) are regarded as pests, however only five (11.6\%) species are regarded as important pests. Bandicota bengalensis is the principal pest while Millardia meltada, Nesokia indica and Mus sp. are the secondary pest species of rice in southern parts of Sindh and major crop growing areas of Punjab, M. meltada and $N$. indica are pests for standing canes in Pakistan. B. bengalensis and M. meltada are the major pests of wheat in irrigated wheat fields of central Punjab and northern Sindh; respectively, Jirds (Meriones sp.) and bandicoot rats damage wheat in rainfed areas of the country (Beg et al., 1977).

It is the reality that no country is free from the devastation of these vertebrate pests, particularly by rodents, which is a cause of severe economic losses resulting in malnutrition and even food crisis. Pakistan, having different climatic zones and with complex cropping patterns and practices, also suffers economic losses due to rodents, birds, wild boars, porcupine, and pikas, etc. Standing cereal crops and stored commodities are affected by rodent and bird pests. Present work was aimed to determine the species composition and population densities of rodent of agricultural importance in rain-fed and irrigated areas of district Swat, Pakistan.

\section{Materials and Methods}

\subsection{Study area}

The present study was conducted in 16 agricultural fields (4 each in Potatoes, maize in rain-fed and irrigated, rice in irrigated areas) of district Swat, Pakistan from April 2011 to November 2013 . It lies $34^{\circ} 34^{\circ}$ to $35^{\circ} 55^{\circ}$ North and $72^{\circ} 08^{\circ}$ to $72^{\circ} 50^{\circ}$ East located in Khyber Pakhtunkhwa province, Pakistan (Khan et al., 2018). The weather is affected by all the climatic factors including, latitude, altitude and rain bearing winds. Water freezing season is from the last of December to the end of February. July is the hottest month of the year. Temperature rises from $16^{\circ} \mathrm{C}$ to $33^{\circ} \mathrm{C}$. January is the coldest month in which temperature ranges from $11^{\circ} \mathrm{C}$ to $-2^{\circ} \mathrm{C}$. The highest recorded rainfall is $242 \mathrm{~mm}$ during March (Normals 1961-1990). Agriculture is the main stay of life followed by livestock.

\subsection{Trapping and population estimation of rodents}

A total of 756 locally available commercial wire mesh live traps of medium size were used for capturing the rodents. All the traps were baited with oily bread, which are attractive by the rodents. At each agricultural field 63 traps for 4consecutive nights were set just after sunset and picked up in the morning. Traps were sited alongside the burrows or where signs of rodent movements were recorded. Cropping stage wise trapping was carried out in each field. Population of the rodents trapped were calculated by applying the following Formula 1:

$$
\begin{aligned}
\% \text { trap success }= & \text { Number of rodent trapped / } \\
& \text { Number of trap nights } \times 100
\end{aligned}
$$

\subsection{Anesthetization of the rodents}

All the rats/mice were anaesthetized with chloroform and the following information were gathered.

\subsection{Visualizing the age and sex of the rodents}

* Body weight: All the rats/mice were weighed using the Precisa balance model No.18220 Switzerland;

* Sex of individuals: On the basis of visual inspection of external sexual organs the sex was determined as: male; when the ano-genital distance was measured usually greater and in female; when the ano-genital distance was measured usually less than male;

* The rodents were considered to be adult if the weight was greater than that of the smallest sexually mature one and using visibility of tubules in case of males or estrous stage in case of females/ perforation of vagina as the criteria of sexual maturity. 


\subsection{Statistical analysis}

The relative abundance of rodents was estimated by using regression of captures on cumulative captures in different crop fields. In this method, rodent captures was plotted against the cumulative captures and a regression line was plotted using the MS Excel program 2007. The intercept point of regression line with $\mathrm{X}$-axis gave the estimated population. Mean and slandered deviation, Mean \pm SEM of column $A$ and B, difference between means, 95\% confidence of interval, $\mathrm{R}$ square and $\mathrm{F}$ test have also been calculated by graphed prism 5 (Table 1 ).

\section{Results}

Rats were trapped more $76.8 \%$ (269/350) than mice $23.1 \%(81 / 350)$ at both rain-fed as well as irrigated areas of Swat district. House rats (Rattus rattus) were trapped in abundance at all the crop fields than house mice (Mus musculus). Rats were usually trapped during all the growth stages of the crops studied than mice. Significant difference was found between the number of rats and mice in growth stages of the crops studied while the difference in between the population density of rats and mice were not significantly different in rain-fed and irrigated areas, in crop fields studied, male and females rode. Other statistics including Mean \pm SEM of column A and B, difference between means, $95 \%$ confidence of interval, $R$ square and $\mathrm{F}$ test have also been calculated (Table 1).

\subsection{Abundance of rodents}

The population abundance indices of Rattus rattus ( $\mathrm{n}=269$ ) was greater than Mus musculus ( $\mathrm{n}=81$ ) but was not statistically different (P value 0.0861 with $95 \%$ confidence of intervals range -14.09 to 139.4) among crop fields. $R$. rattus was the species that numerically predominant in every habitats than M. musculus. M. musculus were usually considered in-house species, where rats are not in abundance. No statistically significance was found between the population density of rain-fed and irrigated areas ( $P$ value is 0.9153 with 95\% confidence of interval range -294.4 to 278.4$) R$. rattus came to be the most abundant in maize fields of rain-fed and rice fields of irrigated areas (Figure 1). Regression of daily captures on cumulative captures (Figure 1) revealed a negative and non-significant correlation, between the captures over time (nights) $(Y=-23.367 x ; R 2=-5.266)$ for rats and $\left(Y=6.9333 x ; R^{2}=-13.43\right)$ for mice.

\subsection{Seasons and sex ratio}

In the present study, rats were trapped more 269 (76.8\%) than mice $81(23.1 \%)$ at both rain-fed as well as irrigated fields of Swat, Pakistan. Adult rats were trapped low in ratio 118 (33.7\%) than sub-adults 151 (43.1\%). Male rats were trapped more 165(47.1\%) than females 104 (29.7\%) but no statistically significance was found (P value 0.1434 with $95 \%$ confidence interval range -14.08 to 67.41 ). Most of the rats $75(21.4 \%)$ were trapped at maize fields followed by potatoes 53(15.1\%) in rain-fed areas and 75(21.4\%) in maize fields followed by rice fields 66(18.8\%) in irrigated areas. Percent trap success was noted at mature/harvesting stage 105(30\%), followed by flowering/fruiting 104(29.7\%) and vegetative stage 60 (17.1\%).this was statistically significant ( $P$ value 0.0174 with $95 \%$ confidence of interval range 18.15 to 107.2 ).

Males were trapped more ( $\mathrm{n}=215)$ than females $(\mathrm{n}=135)$ in both the species but not statistically different (P value 0.3679; Kruskal- Wallis test 3.000). Sex ratio: 1.5:1.0 and 1.61:1 male and female in $R$. rattus and M. musculus respectively were regarded in all the shops studied.

The present data reveals the season wise population abundance as: $77(22 \%), 130$ (37.1\%) and 143 (40.8\%) were trapped during vegetative, flowering/fruiting and mature harvesting stages of the crops studied respectively but not statistically different. Linear regression on Microsoft Excel 7 is $y=54.714 x R^{2}=0.4409$. Highest number of rodents trapped during flowering and fruiting in rice crop fields while the lowest during vegetative stage in potato fields. Crop wise the population abundance of the rodents trapped was: 70 (20\%), 97(27.7\%), 87(24.8\%) and 97(27.7\%) in potatoes, maize (rain-fed), maize (irrigated) and rice. The majority of the rats were trapped at maize crop fields (rain-fed) and rice crop fields (irrigated) (Figure 2).

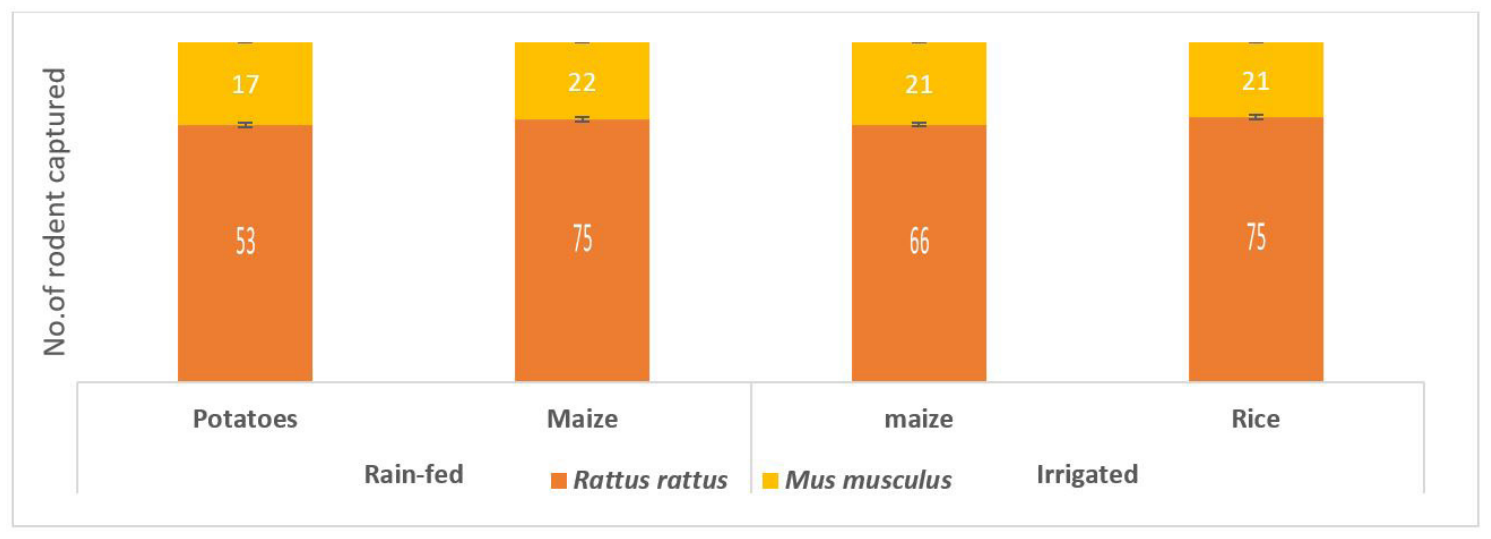

Figure 1. Distribution of rodents in different crop fields of rain-fed and irrigated areas of Swat, Khyber Pakhtunkhwa, Pakistan. 


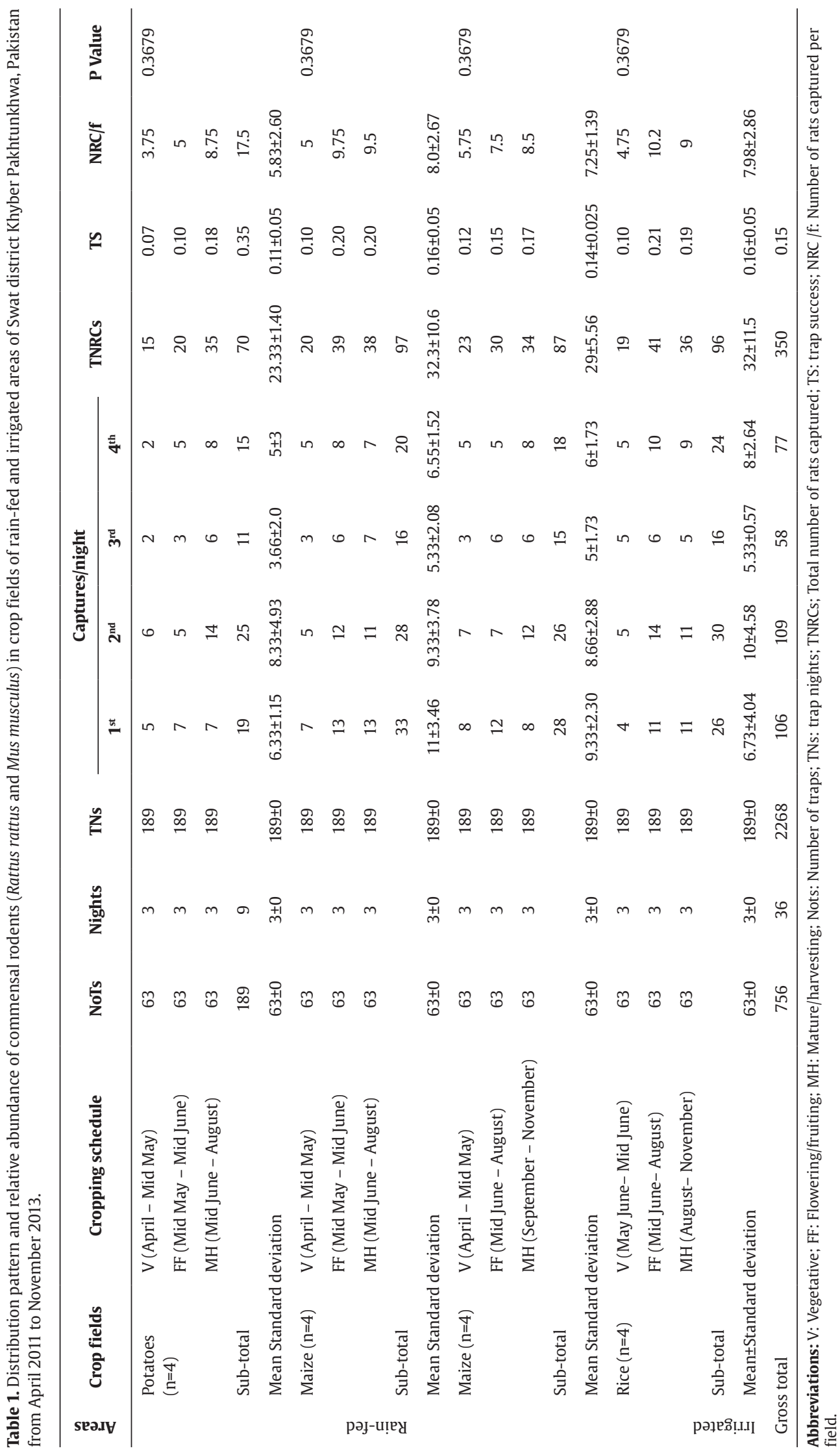




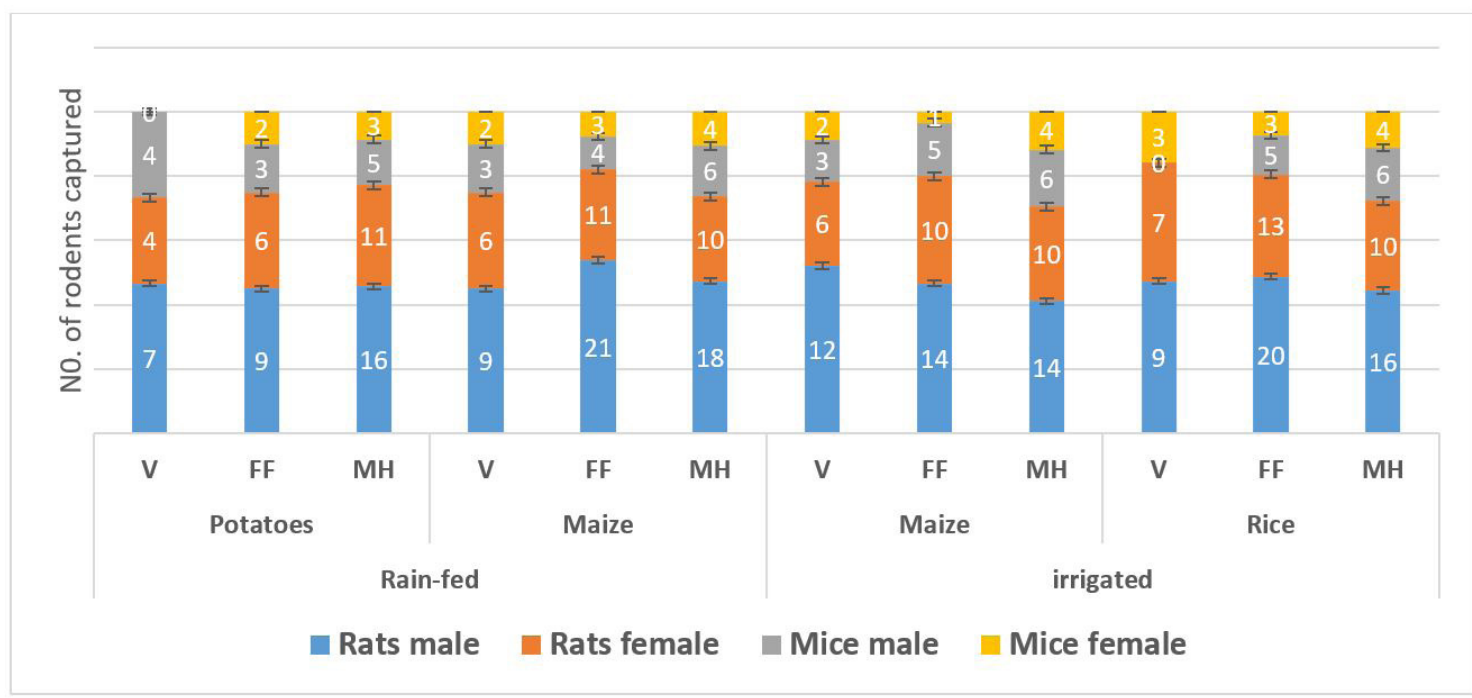

Figure 2. Variation in population dynamics of rodents (Rattus rattus and Mus musculus) in different seasons of the year $(\mathrm{V}=\mathrm{Vegetative;}$ FF=Flowering/fruiting; $\mathrm{MH}=$ Mature/harvesting.

Significant difference was found between the number of rats and mice in various stages of the crops studied while the difference in between the population density of rats and mice were not significantly different in rainfed and irrigated areas, in crop fields male and females. Other statistics including Mean \pm SEM of column $A$ and $B$, difference between means, $95 \%$ confidence of interval, $\mathrm{R}$ square and $\mathrm{F}$ test have also been calculated (Table 1).

\section{Discussion}

Rats and mice have adapted well to the diversity of agricultural habitats created by man. Almost $42 \%$ of all mammalian species are rodents with at least $10 \%$ are significant agricultural pests. Rodents are the ultimate Mammalia living in almost every habitat on earth, yet they also play a fundamental role in nutrient cycling and water flows in many ecosystems and therefore the non-pest species need to be protected (Singleton, 2010). Rats have three main impacts: Substantial damage they can cause at any stage to growing crops, cause losses at post-harvest to stored grain and vegetables and impacts on the health of small holder, farmers. Rodents are carriers of at least 20 severely debilitating diseases to human (Meerburg et al., 2009).

Rats and mice are the important pests of agriculture in Pakistan (Hussain and Pruthi, 1921; Wagle, 1927) and exert serious limitations on the production of a variety of crops throughout Pakistan (Ahmad et al., 1986).

House mice (Mus domestica) serving a serious pest of agricultural crops in Australia can increase in abundance> 1000 mice / ha causes enormous economic and social stress to rural communities (Brown and Singleton, 2000). Densities of mice have been recorded as high as: 2500 and 2716 mice/ha in Australia (Boonstra and Redhead 1994). Mouse densities are highest in autumn and early winter and for summer crop months prior to harvest therefore the damage is also highest (Brown et al., 1997).

In term of population density current study was not in accordance to Saunders and Robards (1983). When the densities of mice reached to 2716/ha it is considered high, while in present study the density of Rattus rattus and Mus musculus reached up to 53/ha and $17 /$ ha at potatoes, 75 /ha and 22/ha at maize fields at rain-fed areas; 66/ha and 21/ha at maize fields, $75 /$ ha and 21/ha at rice of irrigated areas. Present study is accorded to the findings of Brown and Singleton (2000) but contrary in damages. According to them when the rodent abundance is less than $75 /$ ha, it leads to less than $5 \%$ a crop loss which is considered low.

In current study overall $0.15 \%$ trap success was noted which is not in accordance to the study conducted by Siddique and Arshad (2003) calculated $1.35 \%$ of the trap success in wheat fields of Faisalabad, Pakistan. They also noted $4.1 \%$ trap success in sugarcane fields which is not according to the present investigation. Highest \% trap success was $17.1 \%$ for maize fields of rain-fed areas followed by $16.9 \%$ for rice fields of irrigated areas while low $15.3 \%$ for maize fields of irrigated areas and 12.3 for potato fields of rain-fed areas in the present study. The monthly trap success ranges from $0.00-16.00 \%$ in Faisalabad while in present study it ranges from 0.07 to $0.35 \%$. Highest \% trap success was $19.6 \%$ reported for mature/harvesting stage followed by $17.1 \%$ during flowering/fruiting stage and lowest $10.0 \%$ during vegetative stage of the crops.

Sex ratio reflects ability of the species to respond to natural selection (Wu et al., 2006). A 1:1 sex ratio is favored in polygamous species when food is abundant (Wright et al., 1988). Gomez et al. (2008) reported variation in sex ratio in M. musculus in different habitats and seasons in Argentina. This variation has been reported both in commensal (M. musculus) and wild species, where subordinate males increase their area of activity during reproduction (Hernandez-Betancourt et al., 2003), covering 
area in search of food sources or females are generally repelled by dominated males which lead to an increased probability of capture. In contrast with the reproductive females since their area of activity is smaller especially during pregnancy and lactation (Frynta et al., 2005).

In current study males outnumbered the females with the ratio of 1.58: 1.04 for rats and 1.6:1.1 for mice which favour's the findings of Kunimoto et al. (2002) who found a male female ratio of 2.1:1 in population of M. musculus in Panti- May et al. (2012) reported the sex ratio in $M$. musculus and $R$. rattus differed from 1:1 with a higher recorded capture of male. In the present study sub-adults were trapped more in rats and somewhat low in mice this is comparable with the study of (Dickmar, 1999) that low capture rate of young may be due to the greater dominance and aggression of adults and the short time it takes for these rodents to reach sexual maturity (Sidorov and Putin, 2010). It was documented by the similar percentages of juveniles and reproductive individuals found in both species and time periods.

\section{Conclusions and Recommendations}

The current study provides fundamental evidence regarding the distribution and abundance of Rattus rattus and Mus musculus in agricultural fields of Swat district. Further studies are required to explore the impact of these rodents on the human life.

\section{Acknowledgements}

We thanks Dr. Rafia Rehana Ghazi for providing the laboratory facilities and species identification of rodent pests.

\section{References}

AHMAD, M.S., MIAN, M.Y. and BROOKS, J.E., 1986. Bandicoot rat damage in deep water rice fields. International Rice Research Newsletter (Philippines), vol. 11, no. 1, pp. 25.

APLIN, K.P., BROWN, P.R., JACOB, J., KREBS, C. J. and SINGLETON, G.R., 2003. Field methods for rodent studies in Russia and the Indo-Pacific. Melbourne: BPA Print Group, Australian Centre for Agricultural Research, $223 \mathrm{p}$.

BEG, M.A., KHAN, A.A. and YASIN, M., 1977. Rodent damage to wheat crop in Faisalabad district. Pakistan Journal of Agricultural Sciences, vol. 14, pp. 37-44.

BOONSTRA, R. and REDHEAD, T.D., 1994. Population dynamics of an outbreak population of house mice (Mus domesticus) in the irrigated rice-growing area of Australia. Wildlife Research, vol. 21, no. 5, pp. 583-598. http://dx.doi.org/10.1071/WR9940583.

BROWN, P.R. and SINGLETON, G.R., 2000. Impacts of house mice on crops in Australia-costs and damage. USDA National Research Centre Symposia Human conflicts with Wildlife: economics considerations. Lincoln: University of Nebraska, pp 48-57.

BROWN, P.R., SINGLETON, G.R., DUNN, S.C., JONES, D.A., BRIEN, K.O. and GRIFFITHS, J., 1997. A best farm management practices to control mouse populations. Canberra, Australia: CSIRO Wildlife and Ecology. Unpublished report to the Bureau of resource Sciences and the grains Research and Development Corporation.

DICKMAR, C.R., 1999. Rodent ecosystem relationships: a review in ecologically based management of rodent pests. In: G.R. SINGLETON, L.A. HINDS, H. LEIRS and Z. ZHANG, eds. title. Canaberra, Australia: ACIAR, pp. 113-133.

FRYNTA, D., SLABOVA, M., VACHOVA, H., VOLFOVA, R. and MUNCLINGER, P., 2005. Aggression and Commensalism in house mouse: a comparative study across Europe and the near East. Aggressive Behavior, vol. 31, no. 3, pp. 283-293. http://dx.doi. org/10.1002/ab.15555.

GOMEZ, V.I.E., ROBLES, M.R. and BUSCH, M., 2008. Helminth communities and host-parasite relationship in Argentine brown rat (Rattus norvegicus). Helminthologia, vol. 45, no. 3, pp. 126-129. http://dx.doi.org/10.2478/s11687-008-0024-1.

HERNANDEZ-BETANCOURT, S., LOPEZ, W.R., CRIME, P.J. and MEDINA, P.S., 2003. Area de activaded, movimiento y organization social de Heteromys gaumeri Allen Chapman, 1897 (Rodentia: Heteromydae) en una selva mediana subcaducifolia de Yucatan, Mexico. Acta Zoológica Mexicana, vol. 90, pp. 77-91.

HUSSAIN, M.A. and PRUTHI, H.S., 1921. Some observations on the control of field rats in the Punjab. Calcutta, India: Superintendent Government Printing. Pusa. Agricultural Research Institute. Bulletin, no. 135, pp. 174-181.

KHAN, A.A., 1990. Population density and reproduction of house rats living in some sweets and grocery shops in Faisalabad city. Faisalabad, Pakistan: Department Zoology and Fisheries, University of Agriculture, $80 \mathrm{p}$. MSc Thesis.

KHAN, W., UN-NISA, N. and KHAN, A., 2018. Prevalence of Potentially Important Intestinal Pathogenic Protozoan Parasitic Infections in Different Occupational Groups of Swat, Pakistan. Pakistan Journal of Zoology, vol. 50, no. 1. http://dx.doi.org/10.17582/ journal.pjz/2018.50.1.123.129.

KUNIMOTO, C., CRUZ, D.L., ARANA, M. and RAMIREZ, O.E., 2002. Observaciones sobre la ecologia poblacional de raton domestic en Lachay, Peru. Bulletin de IntitutFrancas de Etuds Andienes, vol. 31, pp. 323-328.

LEIRS, H., 2003. Management of rodents in crops: the Pied Piper and his orchestra. In: G.R. SINGLETON, L.A. HINDS, C.J. KREBS and D.M. SPRATT, eds. Rats, mice and people: rodent biology and management. Canberra: Australian Centre for International Agricultural Research, pp. 183-190.

MAKUNDI, R.H., MBISE, T.J. and KILOZO, B.S., 1991. Observations on the role of rodents in crop losses in Tanzania and control strategies. Beiträge zur tropischen Landwirtschaft und Vertirinärmedizin, vol. 4, pp. 465-474.

MEERBURG, G.M., SINGLETON, G.R. and KIJLSTRA, A. 2009. Rodent borne diseases and their risks for public health. Critical Reviews in Micobiology, vol. 35, pp. 221-270.

PANTI-MAY, J.A., HERNÁNDEZ-BETANCOURT, S., RUÍZ-PIÑA, H. and MEDINA-PERALTA, S., 2012. Abundance and population parameters of commensal rodents present in rural households in Yucatan, Mexico. International Biodeterioration E Biodegradation, vol. 66, no. 1, pp. 77-81. http://dx.doi. org/10.1016/j.ibiod.2011.10.006.

SAUNDERS, G.R. and ROBARDS, G.E., 1983. Economic considerations of mouse plague control in irrigated sunflower crops. Crop Protection (Guildford, Surrey), vol. 2, no. 2, pp. 153-158. http:// dx.doi.org/10.1016/0261-2194(83)90040-6.

SHAFI, M.M., PERVEZ, A., AHMAD, S. and AHMAD, S.M., 1990. Role of some taste additives to enhance poison bait acceptance in the black rat, Rattus rattus. International Journal of Pest Management, vol. 36, no. 4, pp. 371-374. 
SIDDIQUE, M. and ARSHAD, M. 2003. Seasonal changes in the abundance of Bandicoota bengalensis in irrigated cropland Faisalabad, Pakistan. Asian Journal of Plant Sciences, vol. 2, no. 1, pp. 145-14. http://dx.doi.org/10.3923/ajps.2003.145.148.

SIDOROV, G.N. and PUTIN, A.V., 2010. The house mouse (Mus musculus L) in Omsk educational institutions: seasonal migration, abundance, reproduction, distribution, foraging and associated damage. Contemporary Problems of Ecology, vol. 3, no. 5, pp. 819-825. http://dx.doi.org/10.1134/S1995425510050164.

SINGLETON, G. R., 2010. Rodents-gnawing away at crops, stored grain and our health. Los Baños: IRRI. Technical Innovation Brief, no. 1.

SINGLETON, G.R., 2003. Impacts of rodents on rice production in Asia. Los Baños: IRRI, pp. 30.

STENSETH, N.C., LEIRS, H., SKONHOFT, A., DAVIS, S.A., PECH, R.P., ANDREASSEN, H.P., SINGLETON, G.R., LIMA, M., MACHANGU, R.M., MAKUNDI, R.H., ZHANG, Z., BROWN, P.B., SHI, D.Y. and WAN, X., 2003. Mice, rats, and people: the bio-economics of agricultural rodent pests. Frontiers in Ecology and the Environment, vol. 1, no. 7, pp. 367-375. http://dx.doi. org/10.1890/1540-9295(2003)001[0367:MRAPTB]2.0.CO;2.
WAGLE, P.V., 1927. The rice rats of lower Sindh and their control. Journal of the Bombay Natural History Society, vol. 32, pp. 330-338.

WILSON, D.E. and REEDER, D.M., 1993. Mammal species of the world: a taxonomic and geographic reference. Washington: Smithsonian Inst.

WOLFF, J.O. and SHERMAN, P.W., 2007. Rodent societies as a model system. In: J. WOLFF and P. SHERMAN, eds. Rodent societies: an ecological and evolutionary perspective. Chicago: The University of Chicago Press, pp. 3-7. http://dx.doi.org/10.7208/ chicago/9780226905389.001.0001.

WRIGHT, S.Y., CRAWFORD, C.B. and ANDERSON, J.L., 1988. Allocation of reproductive effect in Mus domesticus: response of offspring sex ratio and quality to social density and food availability. Behavioral Ecology and Sociobiology, vol. 23, no. 6, pp. 357-366. http://dx.doi.org/10.1007/BF00303709.

WU, S.Y., LIN, Y.K. and YU, T.H., 2006. Population ecology of Southeast Asian house mouse (Muridae: mus musculus castaneus) inhabiting rice granaries in Taiwan. Zoological Studies (Taipei, Taiwan), vol. 45, pp. 467-474. 


\section{BRAZILIAN JOURNAL OF BIOLOGY}

Erratum

\section{Erratum}

In the article "Distribution of commensal rodents in rain-fed and irrigated areas of Swat district, Khyber Pakhtunkhwa, Pakistan”, DOI: http://dx.doi.org/10.1590/1519-6984.236499, published in Braz. J. Biol. vol.82 São Carlos 2022 Epub March 12, 2021, in the section:

Where it reads:

Notes and Comments

It should be read:

Original Article 